\title{
Enhanced thermal oxidative stability of silicone rubber by using cerium-ferric complex oxide as thermal oxidative stabilizer
}

https://doi.org/10.1515/epoly-2019-0026

Received November 07, 2018; accepted December 13, 2018.

\begin{abstract}
Cerium (Ce)-ferric (Fe) complex oxides were prepared via a citric acid sol-gel process, and used as thermal oxidative stabilizers for silicone rubber (SR). The oxides were characterized by X-ray diffraction and Raman spectroscopy. The Ce/Fe molar ratio in Ce-Fe complex oxides significantly influenced the thermal oxidative stability of SR. After aging at $300^{\circ} \mathrm{C}$ for $24 \mathrm{~h}$, SR filled with $4 \mathrm{phr} \mathrm{Ce}-\mathrm{Fe}$ complex oxide with a $\mathrm{Ce} /(\mathrm{Ce}+\mathrm{Fe})$ molar ratio of 0.8 (CeFeO-0.8) exhibited excellent thermal oxidative stability, retaining $56.8 \%$ and $54.3 \%$ of its original tensile strength and elongation at break, respectively. Some $\mathrm{Ce}^{3+}$ and $\mathrm{Fe}^{2+}$ ions were detected in aged SR composites. $\mathrm{Ce}^{3+} / \mathrm{Ce}^{4+}$ and $\mathrm{Fe}^{2+} / \mathrm{Fe}^{3+}$ molar ratios in SR/CeFeO-0.8 were less than that in $\mathrm{SR} / \mathrm{CeO}_{2}$ and $\mathrm{SR} / \mathrm{Fe}_{2} \mathrm{O}_{3}$ composites, respectively, as detected by X-ray photoelectron spectroscopy. It implies rapid re-oxidations of $\mathrm{Fe}^{2+}$ and $\mathrm{Ce}^{3+}$ occurred in SR/CeFeO-0.8, enhancing the capacity of $\mathrm{CeFeO}-0.8$ to capture radicals during thermal aging.
\end{abstract}

Keywords: Ce-Fe complex oxide; silicone rubber; thermal oxidative stability; radical; thermal aging

\section{Introduction}

Silicone rubber (SR) has attracted great attention for its high thermal oxidative stability, which can maintain good performance at $250^{\circ} \mathrm{C}$ for a long time. However, with the

\footnotetext{
* Corresponding author: Yong Zhang, School of Chemistry and Chemical Engineering, State Key Laboratory for Metal Matrix Composite Materials, Shanghai Jiao Tong University, Shanghai 200240, PR China, e-mail: yong_zhang@sjtu.edu.cn, Tel: +86-21-54743261.

Lei Wu, School of Chemistry and Chemical Engineering, State Key Laboratory for Metal Matrix Composite Materials, Shanghai Jiao Tong University, Shanghai 200240, PR China.
}

advancement of frontier technologies, $\mathrm{SR}$ is expected to be used at higher temperature in practical applications. Two competing mechanisms were proposed for describing the degradation process of SR under the presence of heat and oxygen (1-4). The first is the molecular mechanism that occurs with the depolymerization of SR backbone and the formation of cyclic oligomers, which can shorten the length of SR macromolecule chains, consequently leading to the decreasing of crosslink density. The second is the radical mechanism that functions in side chains of SR under oxygen atmosphere where crosslinking reactions take place, causing the increase of crosslink density.

Some thermal resistant additives were used to improve the thermal oxidative stability of SR, e.g., metal oxides (5-10), carbon nanotubes (CNTs) (11-13), graphene (14) and polyhedraloligomeric silsesquioxanes (POSS) $(15,16)$. Among the additives, rare earth oxides and transition metal oxides such as $\mathrm{CeO}_{2}$ and $\mathrm{Fe}_{2} \mathrm{O}_{3}$ have been widely used. SR filled with $\mathrm{CeO}_{2}$ retained $67 \%$ and $62 \%$ of its original tensile strength and elongation at break, respectively, when subjected to thermal aging at $250^{\circ} \mathrm{C}$ for 3 days (6). $\mathrm{Ce}^{4+}$ or $\mathrm{Fe}^{3+}$ ions capture radicals and thus suppress the degradation of $\mathrm{SR}$, which is a well-known antioxidation effect mechanism of metal oxides. A new mechanism was proposed for the antioxidation effect of $\alpha-\mathrm{Fe}_{2} \mathrm{O}_{3}$ for SR at elevated temperature. The redox cycle of $\mathrm{Fe}^{3+}$ occurs on the outer part of SR but $\alpha-\mathrm{Fe}_{2} \mathrm{O}_{3}$ reverts into the form of $\mathrm{Fe}_{3} \mathrm{O}_{4}$ in the inner layer of $\mathrm{SR}$ (8). The synergistic effects of two fillers were also studied. $\mathrm{Fe}_{2} \mathrm{O}_{3}$ modified CNTs was more efficient than $\mathrm{Fe}_{2} \mathrm{O}_{3}$ for improving the thermal oxidative stability of SR, which was attributed to that CNTs could facilitate the shift from $\alpha-\mathrm{Fe}_{2} \mathrm{O}_{3}$ to $\gamma \mathrm{Fe}_{2} \mathrm{O}_{3}$ which is a better stabilizer, and the electron transportation effect of CNTs on $\mathrm{Fe}_{2} \mathrm{O}_{3}(8-10,17)$. CNTs and $\mathrm{SnO}_{2}$ nanoparticles also exhibited a positive synergistic effect on the thermal oxidative stability of SR (12).

Ce-Fe complex oxides were developed for heterogeneous catalysts. The incorporation of a small amount of $\mathrm{Fe}_{2} \mathrm{O}_{3}$ into $\mathrm{CeO}_{2}$ can enhance the redox properties and lattice oxygen mobility of $\mathrm{CeO}_{2}$ by lowering the activation energy of oxygen migration, thus improving 
the catalytic properties of $\mathrm{CeO}_{2}$ (18-21). However, to our knowledge, Ce-Fe complex oxides have not been reported as thermal stabilizers for SR. In this article, Ce-Fe complex oxides were prepared by a citric acid sol-gel method, and were modified with phenyltriethoxysilane to avoid the their aggregation in SR. Ce-Fe complex oxides were then mixed into SR to investigate their effect as thermal oxidative stabilizers.

\section{Experimental}

\subsection{Materials}

$\mathrm{Ce}\left(\mathrm{NO}_{3}\right)_{3} \cdot 6 \mathrm{H}_{2} \mathrm{O}, \quad \mathrm{Fe}\left(\mathrm{NO}_{3}\right)_{3} \cdot 9 \mathrm{H}_{2} \mathrm{O}, \quad$ phenyltriethoxysilane and $\mathrm{NH}_{3} \cdot \mathrm{H}_{2} \mathrm{O}$ were purchased from Shanghai Macklin Biochemical Co., Ltd. Citric acid and ethylene glycol were purchased from Shanghai Lingfeng Chemical Reagent Co., Ltd. Polymethylvinylsiloxane (PMVS)/ silica compound (denoted as SR, $100 \mathrm{phr}$ silicone rubber gum $\left(\mathrm{Mn}=5.9 \times 10^{4}\right.$, vinyl content: $\left.0.26 \mathrm{wt} \%\right)$ filled with 50 phr silica and additives) and 2,5-dimethyl-2,5-di(tert-butylperoxy) hexane (DBPMH) were supplied by Midgold Fine Performance Materials (Shenzhen) Co., Ltd.

\subsection{Preparation of thermal oxidative stabilizer}

$\mathrm{CeO}_{2}, \mathrm{Fe}_{2} \mathrm{O}_{3}$ and Ce-Fe complex oxide (CeFeO) were synthesized via the citric acid sol-gel method by referring to the literature (22). $\mathrm{Ce}\left(\mathrm{NO}_{3}\right)_{3} \cdot 6 \mathrm{H}_{2} \mathrm{O}$ and $\mathrm{Fe}\left(\mathrm{NO}_{3}\right)_{3} \cdot 9 \mathrm{H}_{2} \mathrm{O}$ were dissolved in water according to the molar ratio in Table 1. Citric acid and ethylene glycol were then added slowly into the mixed solution (the molar ratio of citric acid /ethylene glycol/total metal ions was 1.5:1:1). The $\mathrm{pH}$ value of the solution was adjusted to $10-11$ by adding $\mathrm{NH}_{3} \cdot \mathrm{H}_{2} \mathrm{O}$. The solution was kept in a water bath at $80^{\circ} \mathrm{C}$ until the gelation was completed. The as-prepared gel was then dried at $120^{\circ} \mathrm{C}$ for $24 \mathrm{~h}$, followed by heating to $500^{\circ} \mathrm{C}$ at a heating rate of $5^{\circ} \mathrm{C} / \mathrm{min}$ and kept for $4 \mathrm{~h}$ to obtain Ce-Fe complex oxide. A simple mixture of $\mathrm{CeO}_{2}$ and $\mathrm{Fe}_{2} \mathrm{O}_{3}$ with a $\mathrm{Ce} /(\mathrm{Ce}+\mathrm{Fe}$ ) molar ratio of 0.8 (denoted as $\mathrm{CeO}_{2} / \mathrm{Fe}_{2} \mathrm{O}_{3}$ ) was prepared as a reference by directly grinding $\mathrm{CeO}_{2}$ and $\mathrm{Fe}_{2} \mathrm{O}_{3}$ together.

\subsection{Surface modification of thermal oxidative stabilizer}

$1 \mathrm{~g}$ thermal oxidative stabilizer, $0.1 \mathrm{~g}$ phenyltriethoxysilane (PTES) and $20 \mathrm{~mL}$ ethanol were mixed under
Table 1: The formula of $\mathrm{CeO}_{2}, \mathrm{Fe}_{2} \mathrm{O}_{3}$ and $\mathrm{CeFeO}$.

\begin{tabular}{lrr}
\hline Sample & $\begin{array}{r}\mathrm{Ce}\left(\mathrm{NO}_{3}\right)_{3}: \mathrm{Fe}\left(\mathrm{NO}_{3}\right)_{3} \\
(\text { molar ratio) }\end{array}$ & $\mathrm{Ce} /(\mathrm{Ce}+\mathrm{Fe})$ molar ratio \\
\hline $\mathrm{CeO}_{2}$ & $1: 0$ & 1 \\
$\mathrm{CeFeO}-0.8$ & $4: 1$ & 0.8 \\
$\mathrm{CeFeO}-0.6$ & $3: 2$ & 0.6 \\
$\mathrm{CeFeO}-0.4$ & $2: 3$ & 0.4 \\
$\mathrm{CeFeO}-0.2$ & $1: 4$ & 0.2 \\
$\mathrm{Fe}_{2} \mathrm{O}_{3}$ & $0: 1$ & - \\
\hline
\end{tabular}

ultrasonication for $30 \mathrm{~min}$ and stirred at $60^{\circ} \mathrm{C}$ for $6 \mathrm{~h}$. The resultant mixture was centrifugated, and the precipitate was washed with ethanol for three times and dried in a vacuum oven at $60^{\circ} \mathrm{C}$ to obtain modified oxides $\left(\mathrm{m}-\mathrm{CeO}_{2}\right.$, $\mathrm{m}-\mathrm{Fe}_{2} \mathrm{O}_{3}, \mathrm{~m}-\mathrm{CeFeO}$ and $\mathrm{m}-\mathrm{CeO}_{2} / \mathrm{Fe}_{2} \mathrm{O}_{3}$ ).

\subsection{Preparation of SR composites}

150 phr PMVS/silica compound, 4 phr modified or unmodified stabilizer and 2 phr DBPMH were mixed on a two-roll mill. The obtained compound was then cured at $170^{\circ} \mathrm{C}$ under a pressure of $10 \mathrm{MPa}$ for the optimum curing time $t_{90}$. SR filled with $4 \mathrm{phr} \mathrm{m}-\mathrm{CeO}_{2} / \mathrm{Fe}_{2} \mathrm{O}_{3}$ was prepared as a reference. The fabrication process of SR composites was illustrated in Figure 1.

\subsection{Thermal oxidative aging}

The vulcanizates were aged in an air-blowing oven at $300^{\circ} \mathrm{C}$ for $24 \mathrm{~h}$.

\subsection{Characterization and measurement}

X-ray diffraction (XRD) patterns were measured on a Bruker D8 Advance using $\mathrm{Cu} K \alpha$ radiation $(\lambda=1.54 \AA)$. Raman spectra were obtained by using a DXR Raman spectrometer with $532 \mathrm{~nm}$ laser excitation. The morphology of thermal oxidative stabilizer was observed by transmission electron microscopy (TEM, JEOL2100F). And Scanning electron microscope (SEM) images and energy dispersive spectroscopy (EDS) were obtained on a Hitachi S-2150 field-emission SEM system. Fourier transform infrared (FTIR) spectra were obtained on a Perkin Elmer Paragon 1000PC spectrometer as the background from 500-4000 $\mathrm{cm}^{-1}$. X-ray photoelectron spectroscopy (XPS) measurements were performed on an RBD upgraded PHI-5000C ESCA system (Perkin Elmer) 

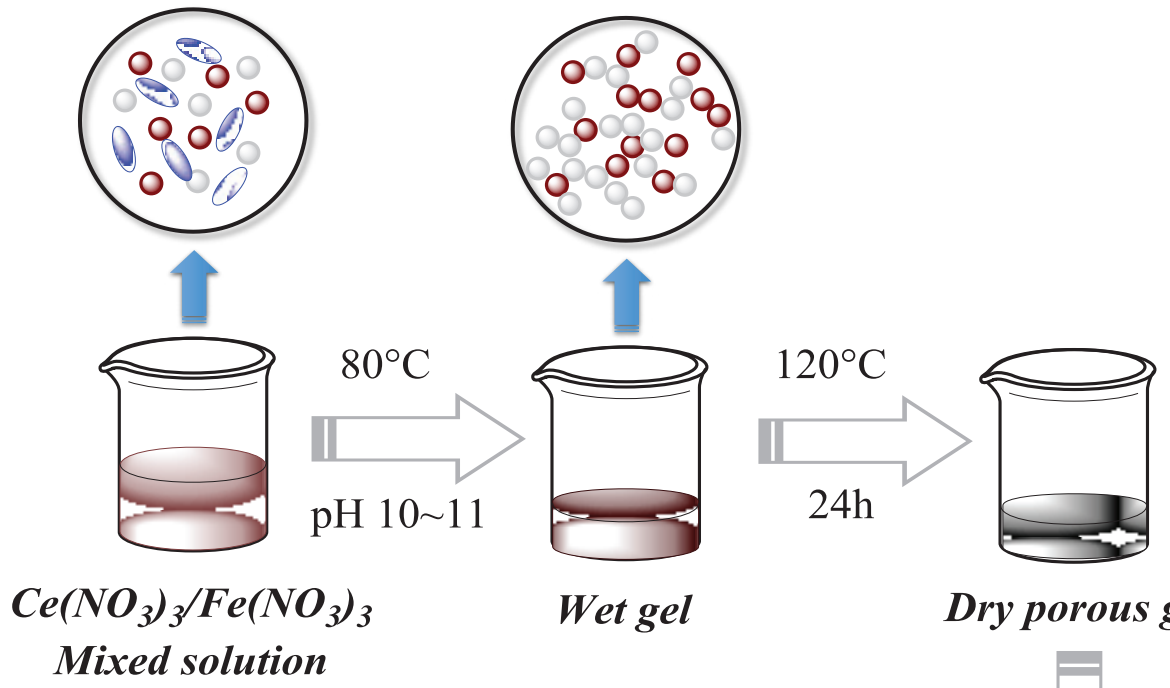

Dry porous gel
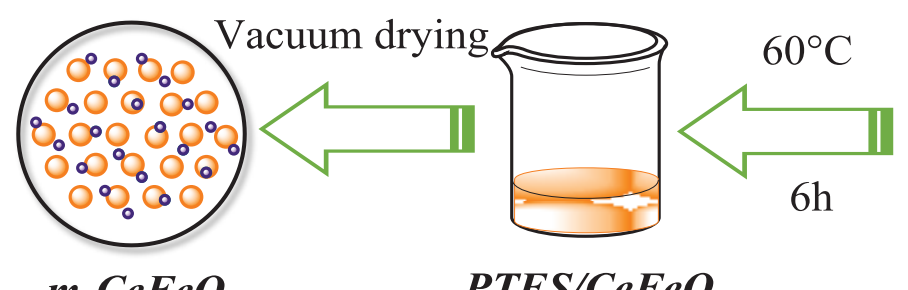

PTES/CeFeO

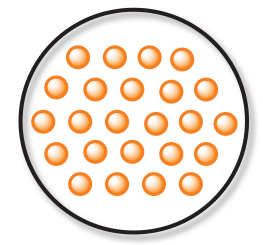

$\mathrm{CeFeO}$

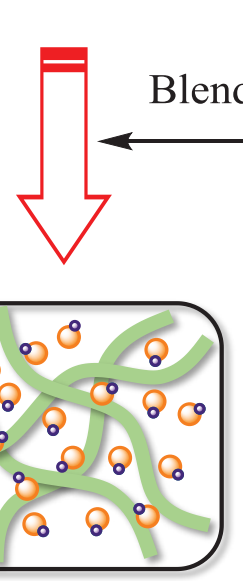

\section{SR/m-CeFeO composites}

Figure 1: The fabrication process of SR composites.

with $\mathrm{Al} K \alpha$ radiation $(h v=1486 \mathrm{eV})$. To eliminate the influence of $\mathrm{Ce}^{3+}$ and $\mathrm{Fe}^{2+}$ produced during the vulcanization and improve the signal intensity of Ce3d and Fe2p XPS spectra, $100 \mathrm{phr}$ silicone rubber gum was filled with $30 \mathrm{phr}$ stabilizer, and the resultant compound was aged at $300^{\circ} \mathrm{C}$ for $48 \mathrm{~h}$. The non-aged and aged samples were used for XPS measurement. The thermal stability was measured through thermogravimetric analysis (TGA) in air atmosphere at a heating rate of $20^{\circ} \mathrm{C} \cdot \mathrm{min}^{-1}$ from 50 to $700^{\circ} \mathrm{C}$ by using a TA Instruments Q5000IR. Stress-strain curves were obtained using a tensile machine (Instron 4465 , USA) at a crosshead speed of $500 \mathrm{~mm} / \mathrm{min}$ at room temperature. The crosslink density of SR vulcanizates was evaluated via the equilibrium swelling method. 
The details of the process and calculation are given in the Supplementary material.

\section{Results and discussion}

\subsection{Characterization of thermal oxidative stabilizer}

XRD patterns and Raman spectra of $\mathrm{CeO}_{2}, \mathrm{Fe}_{2} \mathrm{O}_{3}$ and $\mathrm{CeFeO}$ are shown in Figure 2. All the reflections observed in Figure 2a can be assigned to either $\alpha-\mathrm{Fe}_{2} \mathrm{O}_{3}$ (hexagonal) (23) or cubic $\mathrm{CeO}_{2}$ (fluorite structure) (24). For CeFeO-0.8 and $\mathrm{CeFeO}-0.6$, only reflections from cubic $\mathrm{CeO}_{2}$ are visible, while the simply mixture $\mathrm{CeO}_{2} / \mathrm{Fe}_{2} \mathrm{O}_{3}$ shows the reflections of both cubic $\mathrm{CeO}_{2}$ and $\alpha-\mathrm{Fe}_{2} \mathrm{O}_{3}$. In the patterns of CeFeO0.4 and CeFeO-0.2, reflections are less visible, indicating their amorphous structures which could be related to the high Fe content. Compared with pure $\mathrm{CeO}_{2}$ and $\mathrm{Fe}_{2} \mathrm{O}_{3}$, the $\mathrm{CeO}_{2}$ and $\alpha-\mathrm{Fe}_{2} \mathrm{O}_{3}$ components in the $\mathrm{CeFeO}$ complex oxides exhibits wider and weaker diffraction peaks, which may be attributed to the reduction of crystallite size of $\mathrm{CeO}_{2}$ and $\mathrm{Fe}_{2} \mathrm{O}_{3}$, as caused by the combination of $\mathrm{CeO}_{2}$ and $\mathrm{Fe}_{2} \mathrm{O}_{3}$. The unit cell parameters $(a)$ and crystalline

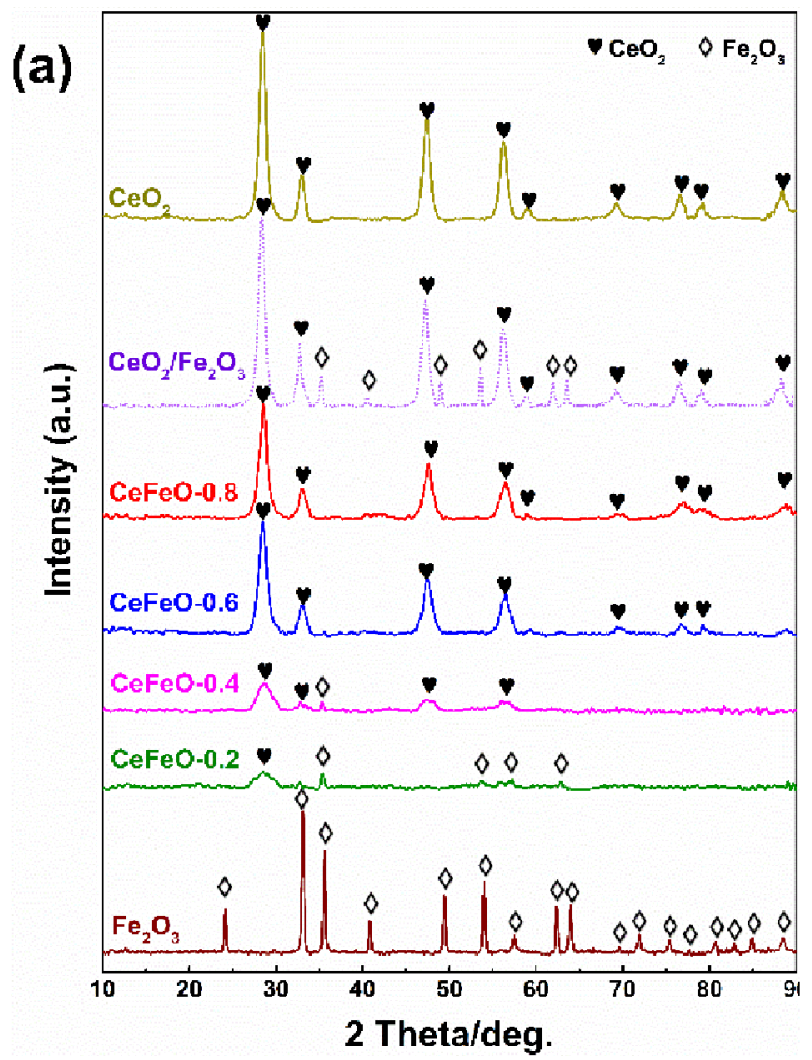

sizes were calculated on the basis of three intensive XRD peaks (111), (220) and (311), and shown in Table 2. The unit cell parameters of cubic $\mathrm{CeO}_{2}$ in $\mathrm{CeFeO}-0.8(5.398 \AA$ ) and CeFeO-0.6 (5.404 $\AA$ ) were a little smaller than that of pure $\mathrm{CeO}_{2}\left(5.411 \AA\right.$ ) , suggesting that $\mathrm{Fe}^{3+}$ has been incorporated into the $\mathrm{CeO}_{2}$ lattice to form a Ce-Fe solid solution, with the contraction of the cell parameter (19,25). CeFeO-0.4 and CeFeO-0.2 had considerable weak intensity of diffraction peaks in XRD patterns, and their unit cell parameter and crystalline size are unable to be calculated.

Figure $2 \mathrm{~b}$ shows the Raman spectra of $\mathrm{CeO}_{2}$, $\mathrm{Fe}_{2} \mathrm{O}_{3}$ and CeFeO. In the spectra of the CeFeO-0.4 and CeFeO-0.2, signals from both $\alpha-\mathrm{Fe}_{2} \mathrm{O}_{3}$ and cubic $\mathrm{CeO}_{2}$ are visible. In the case of the CeFeO-0.8 and CeFeO-0.6, although the Raman spectra for the complex oxides resemble that of pure $\mathrm{CeO}_{2}$, several features should be highlighted. First, the main Raman band $\left(\mathrm{I}_{\text {main }}\right)$ shifted to lower frequency ( $454 \mathrm{~cm}^{-1}$ and $449 \mathrm{~cm}^{-1}$, respectively) with respect to that of pure cubic $\mathrm{CeO}_{2}\left(461 \mathrm{~cm}^{-1}\right)$, which can be ascribed to the decrease in the crystal particle size, resulting in a shift to lower frequency (19). Moreover, a weak and broad band at $598 \mathrm{~cm}^{-1}$ can be observed in the Raman spectra of CeFeO-0.8 and CeFeO-0.6, which is proved to be related to the oxygen vacancies in $\mathrm{CeO}_{2}$ and also a strong

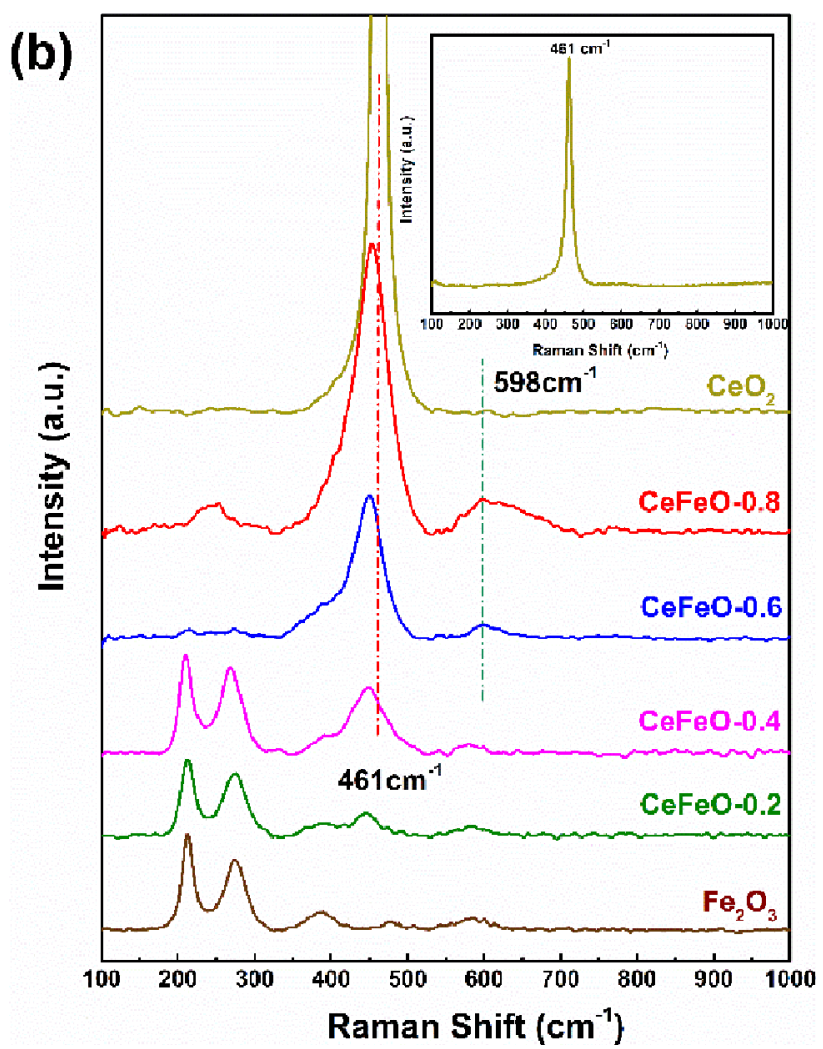

Figure 2: (a) XRD patterns and (b) Raman spectra of $\mathrm{CeFeO}$. The inset in (b) is the Raman spectrum of pure $\mathrm{CeO}_{2}$ with a characteristic peak at $461 \mathrm{~cm}^{-1}$. 
evidence for the formation of Ce-Fe solid solution (26). The intensity ratio of the band at $598 \mathrm{~cm}^{-1}$ and the main Raman band $\left(\mathrm{I}_{598} / \mathrm{I}_{\text {main }}\right)$ was used to estimate the concentration of oxygen vacancies in complex oxides (20). As calculated, $\mathrm{I}_{598} / \mathrm{I}_{\text {main }}$ value for CeFeO-0.8 is 0.11 which is higher than that for CeFeO-0.6 (0.09), suggesting there are more oxygen vacancies in $\mathrm{CeFeO}-0.8$.

The morphology of CeFeO is shown in Figure 3. The particle sizes of CeFeO-0.8 and $\mathrm{CeFeO}-0.6$ are about $10 \mathrm{~nm}$, which are close to the crystalline sizes calculated from XRD. Besides, CeFeO-0.8 has slightly larger particle size than CeFeO-0.6.

\subsection{Effect of PTES on the properties of thermal oxidative stabilizers and SR composites}

The successful modification of the CeFeO-0.8 by PETS proved by FTIR in Figure S1. And the SEM images in Figure S2 present the positive role PTES plays in the dispersion of CeFeO-0.8 in silicone rubber (Supplementary material).

Table 2: The unit cell parameters (a) and crystalline sizes of $\mathrm{CeO}_{2}$ and $\mathrm{CeFeOs.}$

\begin{tabular}{lrr}
\hline Sample & Unit cell parameter, a(Å) & Crystalline size $(\mathrm{nm})$ \\
\hline $\mathrm{CeO}_{2}$ & 5.411 & 11.5 \\
$\mathrm{CeFeO}-0.8$ & 5.398 & 9.8 \\
$\mathrm{CeFeO}-0.6$ & 5.404 & 8.4 \\
\hline
\end{tabular}
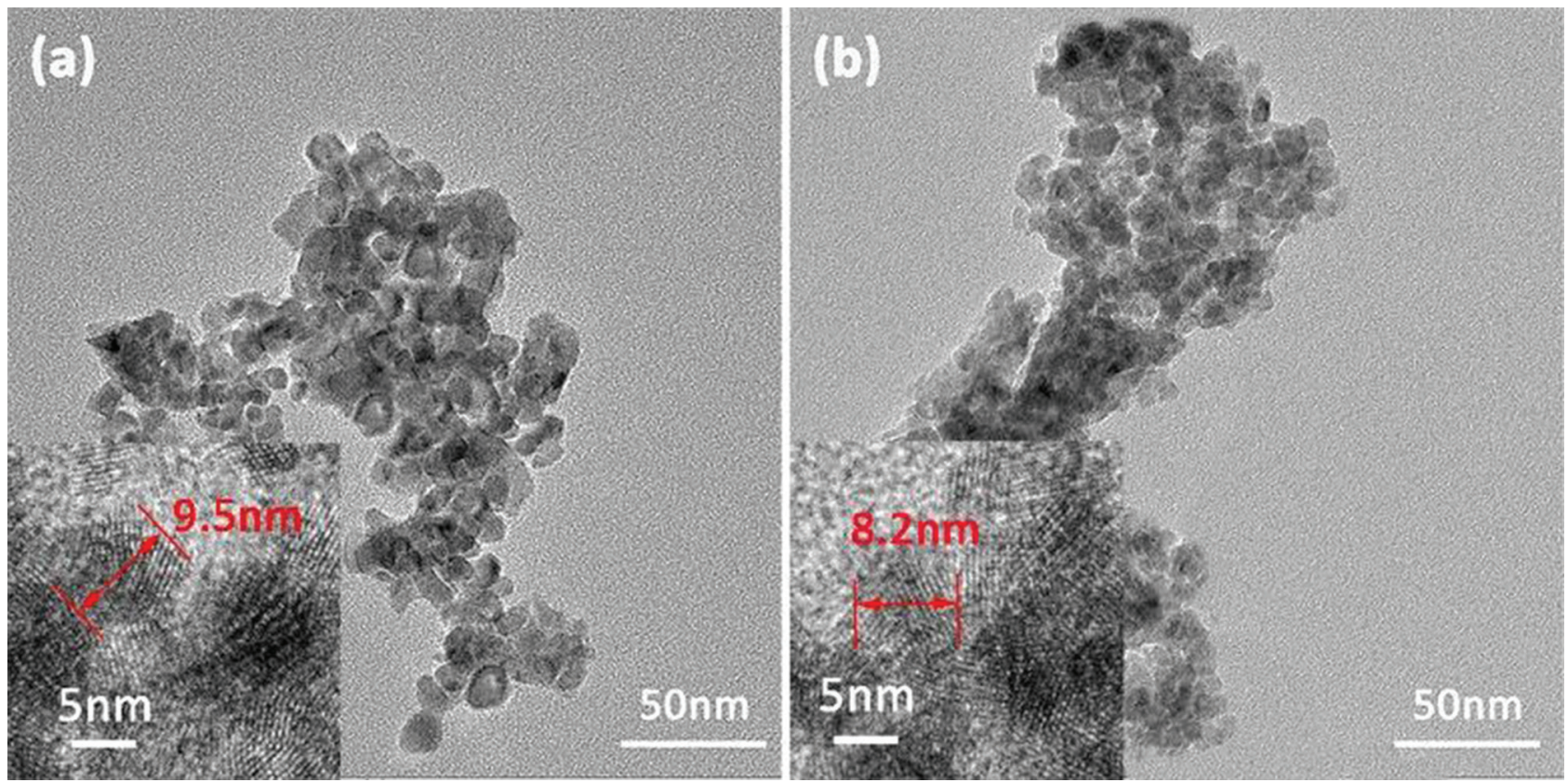

Figure 4 exhibits the modification effect of PTES on the mechanical properties of the SR composites. After modification, the simultaneous increases in the tensile strength and elongation at break of SR can be attributed to the more uniform distribution of CeFeO-0.8 in SR matrix, which is observed in SEM images (Figure S2). Also, the better dispersion of metal oxide particles in SR could be beneficial to the thermal oxidative stability of silicone rubber, which might be associated with the larger specific surface area so caused.

\subsection{Thermal-oxidative aging properties of SR composites}

The mechanical properties of SR composites before and after aging are shown in Figure 5 and Table 3. SR without any thermal oxidative stabilizer showed a cracked and shrunken appearance with a sharp rise in hardness and failed the tensile properties tests after thermal oxidative aging, indicating the occurrence of radical mechanism during thermal oxidative degradation. With the incorporation of $\mathrm{m}-\mathrm{CeFeO}$, the mechanical properties of aged SR composites could be kept to a great extent. However, the anti-oxidative performance of $\mathrm{m}-\mathrm{CeFeO}$ depended on $\mathrm{Ce} / \mathrm{Fe}$ mole ratio. For the tensile strength and elongation at break achieved 56.8\% and $54.3 \%$, respectively, which are the highest among all the composites. m-CeFeO- 0.6 behaved better than aged $\mathrm{SR} / \mathrm{m}$-CeFeO-0.8 composite, the retentions of the

Figure 3: TEM images of CeFeO: (a) CeFeO-0.8; (b) CeFeO-0.6. 

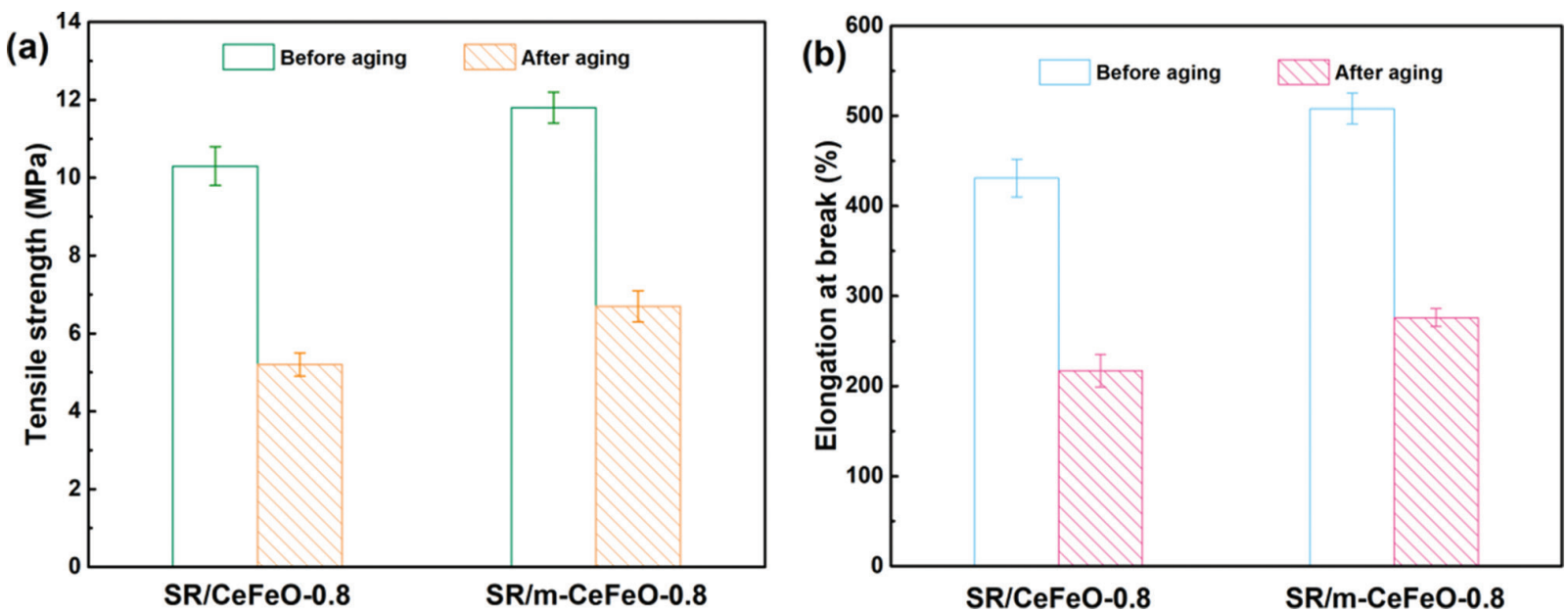

Figure 4: Mechanical properties of SR/CeFeO-0.8 and SR/m-CeFeO-0.8 composites before and after thermal oxidative aging: (a) Tensile strength; (b) Elongation at break.
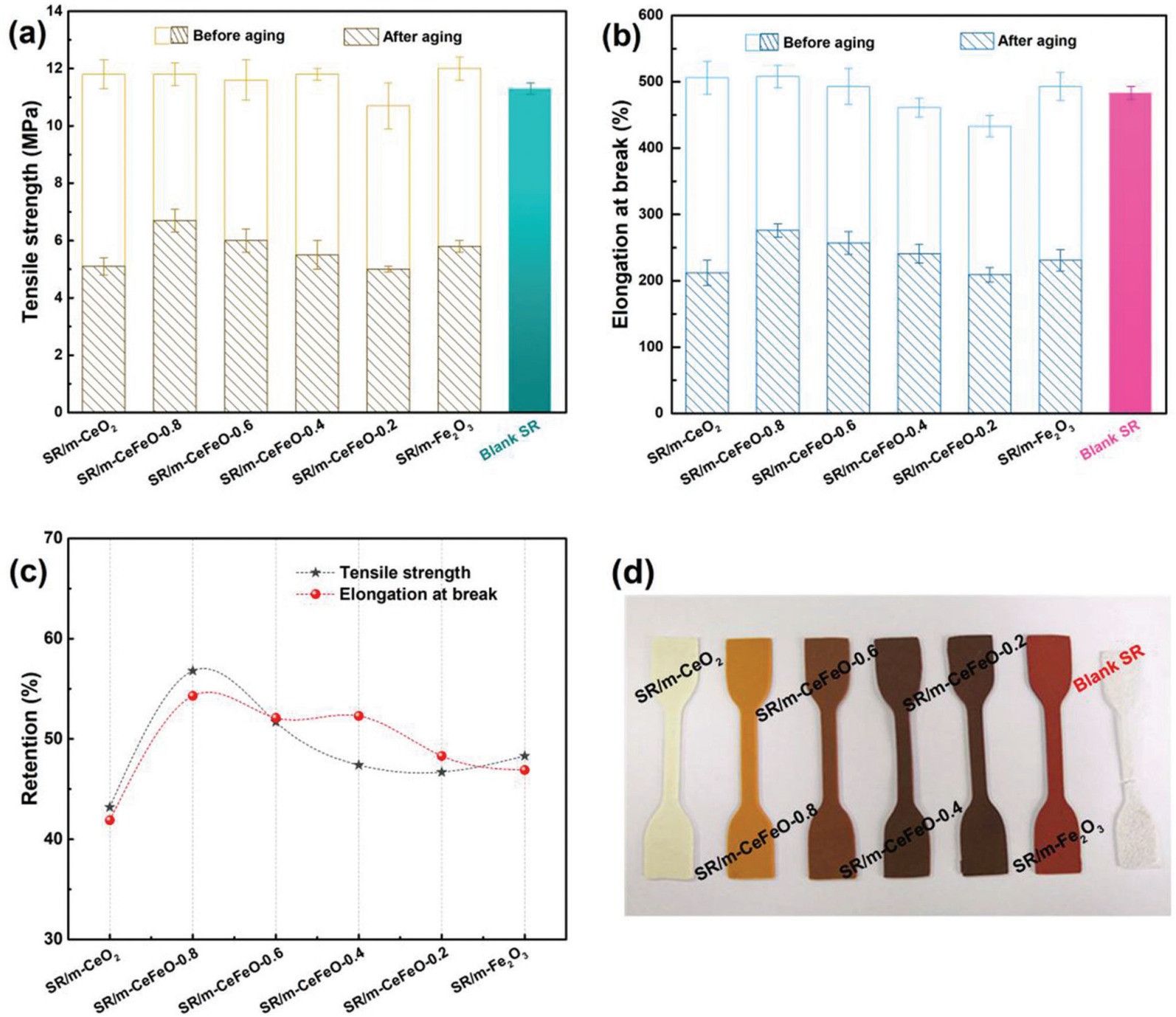

(d)

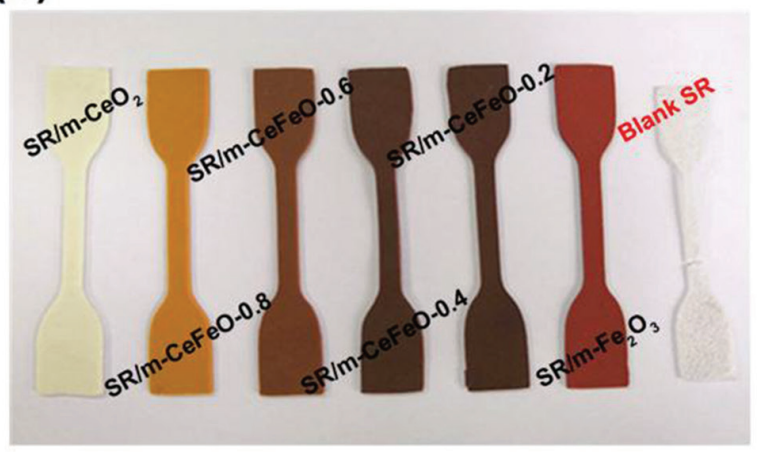

Figure 5: Mechanical properties of SR composites before and after thermal oxidative aging: (a) tensile strength; (b) elongation at break; (c) retentions of tensile strength and elongation at break (d) the photograph of SR composites after aging. 
Table 3: Hardness of SR composites before and after aging.

\begin{tabular}{lcr}
\hline Sample & \multicolumn{2}{c}{ Hardness (Shore A) } \\
\cline { 2 - 3 } & Before aging & After aging \\
\hline $\mathrm{SR} / \mathrm{m}-\mathrm{CeO}_{2}$ & $57.5 \pm 0.5$ & $55.3 \pm 0.7$ \\
$\mathrm{SR} / \mathrm{m}-\mathrm{CeFeO}-0.8$ & $57.5 \pm 0.4$ & $55.9 \pm 0.4$ \\
$\mathrm{SR} / \mathrm{m}-\mathrm{CeFeO}-0.6$ & $58.1 \pm 0.5$ & $56.1 \pm 0.4$ \\
$\mathrm{SR} / \mathrm{m}-\mathrm{CeFeO}-0.4$ & $57.7 \pm 0.7$ & $55.7 \pm 0.5$ \\
$\mathrm{SR} / \mathrm{m}-\mathrm{CeFeO}-0.2$ & $58.7 \pm 0.4$ & $56.7 \pm 0.3$ \\
$\mathrm{SR} / \mathrm{m}-\mathrm{Fe}_{2} \mathrm{O}_{3}$ & $58.3 \pm 0.6$ & $56.3 \pm 0.5$ \\
$\mathrm{Blank} \mathrm{SR}$ & $57.3 \pm 0.6$ & $96.4 \pm 0.6$ \\
\hline
\end{tabular}

$\mathrm{m}-\mathrm{CeO}_{2}$ and $\mathrm{m}-\mathrm{Fe}_{2} \mathrm{O}_{3}$ in improving the thermal oxidative stability of silicone rubber. This could be ascribed to the high oxygen vacancies content caused by the incorporation of $\mathrm{Fe}^{3+}$ into $\mathrm{CeO}_{2}$ lattice. Previous study showed that small doping amount of $\mathrm{Fe}^{3+}$ into $\mathrm{CeO}_{2}$ facilitated the formation of oxygen vacancies whereas large doping amount of $\mathrm{Fe}^{3+}$ annihilated oxygen vacancies (20). Our Raman results demonstrate that there are little oxygen vacancies in $\mathrm{CeFeO}-0.4$ and CeFeO-0.2 samples. The oxygen vacancies existed in CeFeO-0.8 and CeFeO-0.6 could enhance the radical capturing ability of the complex oxides, which benefits the thermal stability of SR.

\subsection{The measurement of the average molecular weight between crosslinking knots $\left(M_{c}\right)$ of SR composites}

Swelling measurements were carried out to further explore the effect of $\mathrm{CeFeO}$ on the thermal-oxidative stability of SR. The changing amplitude of $M_{c}$ of SR before and after aging is calculated by Eq. 1:

$$
\begin{aligned}
& \text { Decreasing } \\
& \text { amplitude }
\end{aligned}=\frac{\left.M_{C} \text { (Before aging }\right)-M_{C}(\text { After aging })}{\left.M_{C} \text { (Before aging }\right)}
$$

The different decreasing amplitudes in $M_{c}$ of SR composites before and after aging can give an indirect indication for their thermal stability and degradation mechanism. As shown in Table 4, the $M_{c}$ of SR composites decreased after thermal aging under air atmosphere, which confirms it is the radical mechanism that mainly occurs during degradation process of SR under the experimental conditions of thermal aging. Focusing on the $M_{c}$ decreasing amplitudes before and after aging, it is observed that the minimum variation of $M_{c}$
Table 4: $M_{c}$ of SR composites before and after thermal oxidative aging.

\begin{tabular}{|c|c|c|c|}
\hline \multirow[t]{2}{*}{ Sample } & \multicolumn{2}{|c|}{$M_{c} \times 10^{-3}$} & \multirow{2}{*}{$\begin{array}{l}\text { *Decreasing } \\
\text { amplitude } / \%\end{array}$} \\
\hline & Before aging & After aging & \\
\hline $\mathrm{SR} / \mathrm{m}-\mathrm{CeO}_{2}$ & 3.48 & 2.80 & 19.5 \\
\hline $\mathrm{SR} / \mathrm{m}-\mathrm{CeFeO}-0.8$ & 3.50 & 3.18 & 9.1 \\
\hline $\mathrm{SR} / \mathrm{m}-\mathrm{CeFeO}-0.6$ & 3.52 & 3.10 & 12.0 \\
\hline $\mathrm{SR} / \mathrm{m}-\mathrm{CeFeO}-0.4$ & 3.32 & 2.72 & 18.1 \\
\hline $\mathrm{SR} / \mathrm{m}-\mathrm{CeFeO}-0.2$ & 3.41 & 2.76 & 19.1 \\
\hline $\mathrm{SR} / \mathrm{m}-\mathrm{Fe}_{2} \mathrm{O}_{3}$ & 3.35 & 2.88 & 14.0 \\
\hline
\end{tabular}

can be achieved by SR/m-CeFeO-0.8 composite, while $\mathrm{SR} / \mathrm{m}-\mathrm{CeO}_{2}$ performed worst among all SR composites. It is obvious that $\mathrm{m}-\mathrm{CeFeO}-0.8$ and $\mathrm{m}$-CeFeO-0.6 function better on the thermal resistance of SR compared with pure $\mathrm{m}-\mathrm{CeO}_{2}$ and $\mathrm{m}-\mathrm{Fe}_{2} \mathrm{O}_{3}$. This can be ascribed to the successful combination of $\mathrm{CeO}_{2}$ and $\mathrm{Fe}_{2} \mathrm{O}_{3}$ in both complex oxides where oxygen vacancies have their share on the oxygen migration and metal ions play their roles on the radical capturing.

\subsection{TGA curves of SR composites}

The thermal stability of SR composites is reflected by TGA curves in Figure 6. And the corresponding characteristic data are listed in Table 5 . All the samples underwent two steps of thermal oxidative degradation. The first one (weight loss ca. 10\%) should be ascribed to the decomposition of low molecular mass additives and polyvinylsiloxane. In this step, a very significant feature is that the initial mass loss temperature of blank SR without heat resistant additive is at least about $30^{\circ} \mathrm{C}$ lower than those of SR composites, demonstrating the positive effect of modified stabilizer on the thermal oxidative degradation process of SR. And the second step is the main weight loss step which was chosen to compare the effect of additives on the thermal oxidative stability of SR. A temperature at weight loss of 50\% $\left(T_{50}\right)$ can reflect the thermalstability ofSRcomposites. Theaddition ofm-CeFeO0.8 can significantly improve $T_{50}$ from $541.7^{\circ} \mathrm{C}$ to $569.8^{\circ} \mathrm{C}$, while the value for $\mathrm{SR} / \mathrm{m}-\mathrm{CeO}_{2} / \mathrm{Fe}_{2} \mathrm{O}_{3}$ is just $557.7^{\circ} \mathrm{C}$. Besides, SR $/ \mathrm{m}-\mathrm{CeFeO}-0.8$ got the highest $T_{\text {Heatresistance index }}$ $\left(T_{H R I}\right)$ of $235.3^{\circ} \mathrm{C}$ among all the composites, indicating the prominent function of $\mathrm{m}-\mathrm{CeFeO}-0.8$ to improve the thermal oxidative stability of SR (27-29). The TGA results of SR composites are consistent with the mechanical properties results. 


\subsection{FTIR spectra of SR composites before and after aging}

Figure 7 displays the FTIR spectra of SR composites which were applied to explore the status of the side groups before and after thermal oxidative aging. Two peaks stand out in the spectra at $1004 \mathrm{~cm}^{-1}$ and $784 \mathrm{~cm}^{-1}$ which could be ascribed to Si-O-Si and $\mathrm{Si}-\mathrm{CH}_{3}$. The intensity of the peak belongs to Si-O-Si group turn stronger after thermal oxidative aging while the intensity of the $\mathrm{Si}-\mathrm{CH}_{3}$ peak become weaker after aging, demonstrating that the destruction of side methyl and the formation of new Si-O-Si groups under the action of heat and oxygen. To further compare the effect of different

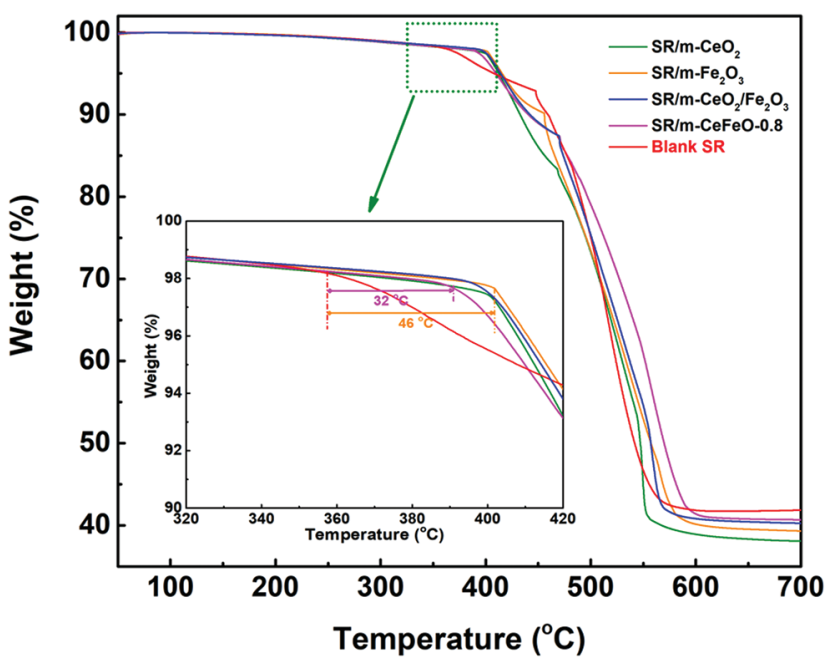

Figure 6: TGA curves of SR composites under air atmosphere.

Table 5: The characteristic data obtained from TGA curves (air, $20^{\circ} \mathrm{C} / \mathrm{min}$ ).

\begin{tabular}{lrrrrr}
\hline Sample & \multicolumn{3}{c}{ Weight loss } & ${ }^{*} T_{\text {HRI }} /{ }^{\circ} \mathrm{C}$ & Residue $/ \%$ \\
& \multicolumn{7}{c}{ temperature $/{ }^{\circ} \mathrm{C}$} \\
& $T_{5}$ & $T_{30}$ & $T_{50}$ & & \\
\hline $\mathrm{SR} / \mathrm{m}-\mathrm{CeO}_{2}$ & 412.6 & 508.0 & 547.0 & 230.2 & 38.3 \\
$\mathrm{SR} / \mathrm{m}-\mathrm{CeO}_{2} / \mathrm{Fe}_{2} \mathrm{O}_{3}$ & 413.7 & 511.3 & 557.7 & 231.4 & 40.3 \\
$\mathrm{SR} / \mathrm{m}-\mathrm{CeFeO}-0.8$ & 409.9 & 527.2 & 569.8 & 235.3 & 40.8 \\
$\mathrm{SR} / \mathrm{m}-\mathrm{CeFeO}-0.6$ & 405.8 & 516.8 & 560.9 & 231.4 & 40.7 \\
$\mathrm{SR} / \mathrm{m}-\mathrm{CeFeO}-0.4$ & 414.8 & 509.2 & 546.6 & 231.0 & 40.9 \\
$\mathrm{SR} / \mathrm{m}-\mathrm{CeFeO}-0.2$ & 413.6 & 510.8 & 547.9 & 231.2 & 40.3 \\
$\mathrm{SR} / \mathrm{m}-\mathrm{Fe}{ }_{2} \mathrm{O}_{3}$ & 415.6 & 509.2 & 557.4 & 231.2 & 39.3 \\
$\mathrm{Blank} \mathrm{SR}$ & 408.0 & 508.8 & 541.7 & 229.5 & 42.3 \\
\hline
\end{tabular}

*The sample's heat-resistance index is calculated by Eq. 2

$$
T_{H R I}=0.49 \times\left[T_{5}+0.6 \times\left(T_{30}-T_{5}\right)\right]
$$

$T_{5}$ and $T_{30}$ are the temperatures at weight losses of $5 \%$ and $30 \%$, respectively.

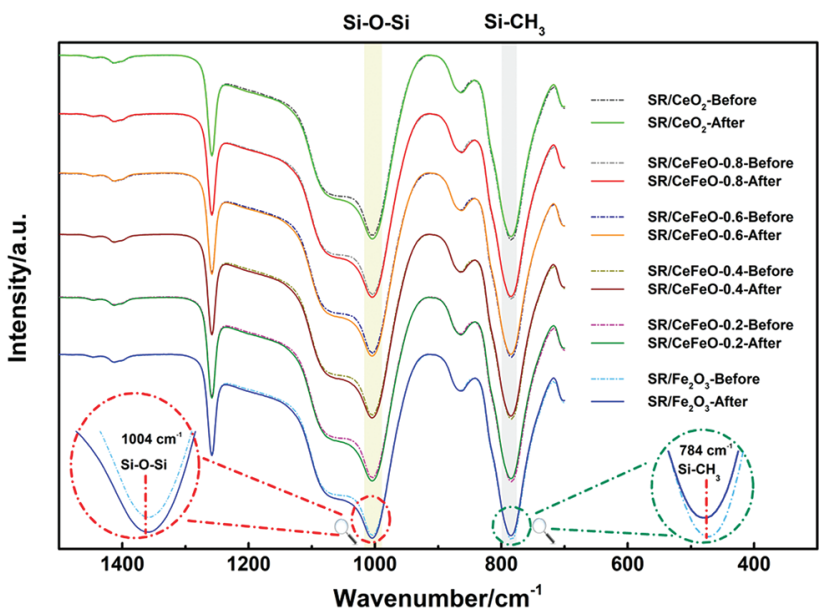

Figure 7: FTIR spectra of SR composites before and after thermal oxidative aging.

Table 6: The absorption intensity and conservation rate obtained from FTIR spectra.

\begin{tabular}{llrrr}
\hline Sample & Aging & $\boldsymbol{A b s}_{\text {Si-0-Si }}$ & $\boldsymbol{A b}_{\text {Si-CH }_{3}}$ & $\boldsymbol{R}(\%)$ \\
\hline $\mathrm{SR} / \mathrm{m}-\mathrm{CeO}_{2}$ & Before & 1.131 & 1.291 & \\
& After & 1.242 & 1.160 & 81.8 \\
$\mathrm{SR} / \mathrm{m}-\mathrm{CeFeO}-0.8$ & Before & 1.145 & 1.308 & \\
& After & 1.215 & 1.207 & 89.8 \\
$\mathrm{SR} / \mathrm{m}-\mathrm{CeFeO}-0.6$ & Before & 1.131 & 1.269 & \\
& After & 1.223 & 1.172 & 85.4 \\
$\mathrm{SR} / \mathrm{m}-\mathrm{CeFeO}-0.4$ & Before & 1.149 & 1.295 & \\
& After & 1.237 & 1.173 & 84.1 \\
$\mathrm{SR} / \mathrm{m}-\mathrm{CeFeO}-0.2$ & Before & 1.152 & 1.296 & \\
& After & 1.237 & 1.154 & 82.9 \\
$\mathrm{SR} / \mathrm{m}-\mathrm{Fe}_{2} \mathrm{O}_{3}$ & Before & 1.151 & 1.299 & \\
& After & 1.244 & 1.155 & 82.2 \\
\hline
\end{tabular}

$\mathrm{CeFeO}$, the conservation rate $(R)$ of the side methyl group were calculated as follows (30):

$$
\begin{array}{r}
A b s_{\mathrm{Si}-\mathrm{CH}_{3}} \text { (After aging) } \times \\
\text { Conservation rate }(R)=\frac{A b s_{\mathrm{Si}-\mathrm{O}-\mathrm{Si}} \text { (Before aging) }}{A b s_{\mathrm{Si}-\mathrm{O}-\mathrm{Si}} \text { (After aging) } \times} \\
A b s_{\mathrm{Si}-\mathrm{CH}_{3}} \text { (Before aging) }
\end{array}
$$

where, $A b s_{\text {Si-CH3 }}$ and $A b s_{\text {Si-OSi }}$ are the absorption intensity of $\mathrm{Si}-\mathrm{CH}_{3}$ and $\mathrm{Si}-\mathrm{O}-\mathrm{Si}$ peaks, respectively, which can be calculated through the transmittance intensity $(T)$ :

$$
A b s=-\lg T
$$

The absorption intensity and $R$ are listed in Table 6 . After aging, $R$ values of SR composites, especially $\mathrm{SR} / \mathrm{m}-\mathrm{CeFeO}-0.8$, are higher than that of $\mathrm{SR} / \mathrm{m}-\mathrm{CeO}_{2}$ and 

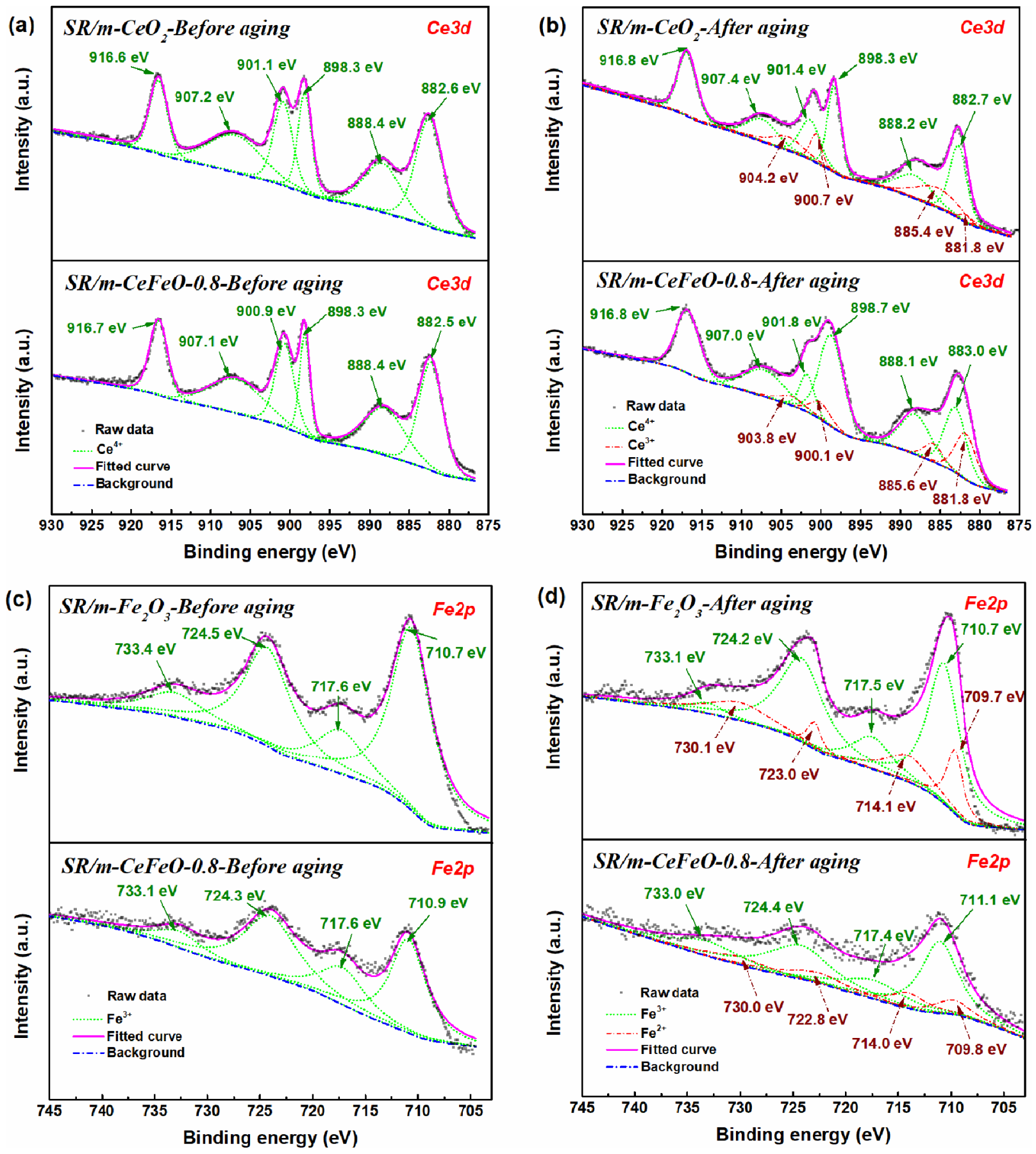

Figure 8: XPS spectra of Ce3d and Fe2p for SR composites before and after thermal oxidative aging: (a) Ce3d XPS spectra before aging; (b) Ce3d XPS spectra after aging; (c) Fe2p XPS spectra before aging; and (d) Fe2p XPS spectra after aging.

$\mathrm{SR} / \mathrm{m}-\mathrm{Fe}_{2} \mathrm{O}_{3}$, indicating that the combination of $\mathrm{CeO}_{2}$ and $\mathrm{Fe}_{2} \mathrm{O}_{3}$ could effectively protect the side methyl groups from attacking by heat and oxygen.

\subsection{XPS of SR compounds and composites}

To study the radical capturing capability of metal oxides during the degradation process of silicone rubber,
$\mathrm{SR} / \mathrm{m}-\mathrm{CeO}_{2} \quad(100 / 30), \quad \mathrm{SR} / \mathrm{m}-\mathrm{Fe}_{2} \mathrm{O}_{3} \quad(100 / 30) \quad$ and $\mathrm{SR} / \mathrm{m}-\mathrm{CeFeO}-0.8$ (100/30) compounds were prepared and kept at an oven at $300^{\circ} \mathrm{C}$ for $48 \mathrm{~h}$, and the aged and non-aged samples were characterized by XPS. The high-resolution XPS spectra of Ce3d and Fe2p for $\mathrm{SR} / \mathrm{m}-\mathrm{CeO}_{2}, \mathrm{SR} / \mathrm{m}-\mathrm{Fe}_{2} \mathrm{O}_{3}$ and SR/m-CeFeO-0.8 compounds before after thermal oxidative aging are shown in Figure 8, and the characteristic data are listed in Table 7. 
Table 7: The characteristic data of XPS spectra.

\begin{tabular}{|c|c|c|}
\hline Samples & Binding energy (eV) & Peak area (\%) \\
\hline \multicolumn{3}{|c|}{ Aged SR/m-CeO 2 composite } \\
\hline $\mathrm{Ce}^{4+}$ & 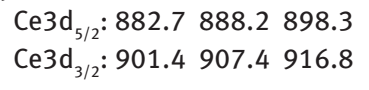 & 77.8 \\
\hline $\mathrm{Ce}^{3+}$ & 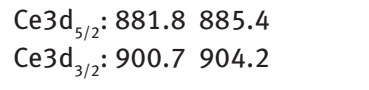 & 22.2 \\
\hline \multicolumn{3}{|c|}{ Aged $\mathrm{SR} / \mathrm{m}-\mathrm{Fe}_{2} \mathrm{O}_{3}$ composite } \\
\hline $\mathrm{Fe}^{3+}$ & $\begin{array}{l}\mathrm{Fe} 2 \mathrm{p}_{3 / 2}: 710.7717 .5 \\
\mathrm{Fe} 2 \mathrm{p}_{1 / 2}: 724.2733 .1\end{array}$ & 72.4 \\
\hline $\mathrm{Fe}^{2+}$ & $\begin{array}{l}\mathrm{Fe} 2 \mathrm{p}_{3 / 2}: 709.7714 .1 \\
\mathrm{Fe} 2 \mathrm{p}_{1 / 2}: 723.0730 .1\end{array}$ & 27.6 \\
\hline \multicolumn{3}{|c|}{ Aged SR/m-CeFeO- 0.8 composite } \\
\hline $\mathrm{Ce}^{4+}$ & $\begin{array}{lll}\mathrm{Ce} 3 d_{5 / 2}: 883.0 & 888.1 & 898.7 \\
\mathrm{Ce}_{3} \mathrm{~d}_{3 / 2}: 901.8 & 907.0 & 916.8\end{array}$ & 80.2 \\
\hline $\mathrm{Ce}^{3+}$ & $\begin{array}{l}\mathrm{Ce} 3 d_{5 / 2}: 881.8885 .6 \\
\mathrm{Ce} 3 d_{3 / 2}: 900.1903 .8\end{array}$ & 19.8 \\
\hline $\mathrm{Fe}^{3+}$ & $\begin{array}{l}\mathrm{Fe}_{2} \mathrm{p}_{3 / 2}: 711.1717 .4 \\
\mathrm{Fe} 2 \mathrm{p}_{1 / 2}: 724.4733 .0\end{array}$ & 75.3 \\
\hline $\mathrm{Fe}^{2+}$ & $\begin{array}{l}\mathrm{Fe}_{2} \mathrm{p}_{3 / 2}: 709.8714 .0 \\
\mathrm{Fe} 2 \mathrm{p}_{1 / 2}: 722.8730 .0\end{array}$ & 24.7 \\
\hline
\end{tabular}

As shown in Figure 8a, there is no $\mathrm{Ce}^{3+}$ in non-aged $\mathrm{SR} / \mathrm{m}-\mathrm{CeO}_{2}$ and $\mathrm{SR} / \mathrm{m}-\mathrm{CeFeO}-0.8$ compounds. After aging, the SR compounds became vulcanizates, implying the occurrence of radical mechanism. In Figure $8 \mathrm{~b}$, the Ce3d XPS spectra retained the $\mathrm{Ce}^{4+}$ peaks $\left(3 \mathrm{~d}_{5 / 2}=882.7-883.0 \mathrm{eV}\right.$, 888.1-888.2 $\mathrm{eV}$ and 898.3-898.7 eV; $3 \mathrm{~d}_{3 / 2}=901.4-901.8 \mathrm{eV}$, 907.0-907.4 eV and $916.8 \mathrm{eV}$ ). Moreover, the satellite peaks at 885.4-885.6 eV indicate the existence of $\mathrm{Ce}^{3+}$. Besides, other peaks $\left(3 \mathrm{~d}_{5 / 2}=881.8 \mathrm{eV} ; 3 \mathrm{~d}_{3 / 2}=900.1-900.7 \mathrm{eV}\right.$ and 903.8-904.2 eV) are also associated with $\mathrm{Ce}^{3+}(21,31,32)$. The results indicated the partially conversion of $\mathrm{Ce}^{4+}$ to $\mathrm{Ce}^{3+}$ in aged SR composites. Similarly, Figure 8c shows there is no $\mathrm{Fe}^{2+}$ in non-aged $\mathrm{SR} / \mathrm{m}-\mathrm{Fe}_{2} \mathrm{O}_{3}$ and $\mathrm{SR} / \mathrm{m}$-CeFeO-0.8 compounds, while the Fe2p XPS spectra in Figure 8d show the co-existence of $\mathrm{Fe}^{3+}$ and $\mathrm{Fe}^{2+}$ in aged samples $(33,34)$. As shown in Table 7, the aged SR/m-CeFeO-0.8 composite got a $\mathrm{Fe}^{3+} /\left(\mathrm{Fe}^{3+}+\mathrm{Fe}^{2+}\right)$ ratio of $75.3 \%$ and a $\mathrm{Fe}^{2+} /\left(\mathrm{Fe}^{3+}+\mathrm{Fe}^{2+}\right)$ ratio of $24.7 \%$, while the contents of $\mathrm{Ce}^{4+} /\left(\mathrm{Ce}^{4+}+\mathrm{Ce}^{3+}\right)$ and $\mathrm{Ce}^{3+} /\left(\mathrm{Ce}^{4+}+\mathrm{Ce}^{3+}\right)$ in the aged SR/m-CeFeO-0.8 composite are about $80.2 \%$ and $19.8 \%$, respectively. The results indicate that $\mathrm{Fe}^{3+}$ behaves very active in radical quenching. Moreover, compared with $\mathrm{SR} / \mathrm{m}-\mathrm{CeO}_{2}$ and $\mathrm{SR} / \mathrm{m}-\mathrm{Fe}_{2} \mathrm{O}_{3}$, $\mathrm{SR} / \mathrm{m}-\mathrm{CeFeO}-0.8$ composite has less ratios of $\mathrm{Fe}^{2+} /\left(\mathrm{Fe}^{3+}+\mathrm{Fe}^{2+}\right)$ and $\mathrm{Ce}^{3+} /\left(\mathrm{Ce}^{4+}+\mathrm{Ce}^{3+}\right)$ after aging. Previous studies in the field of catalysis confirm that the incorporation of low-state $\mathrm{Fe}^{3+}$ into $\mathrm{CeO}_{2}$ lattice could facilitate the migration of oxygen, leading to a fast re-oxidation of $\mathrm{Fe}^{2+}$ and $\mathrm{Ce}^{3+}$, then a redox cycle is formed. Therefore, the synergistic effect of $\mathrm{CeO}_{2}$ and $\mathrm{Fe}_{2} \mathrm{O}_{3}$ in $\mathrm{CeFeO}$ on the thermal oxidative stability of silicone rubber may be related to the fast redox cycle occurred in $\mathrm{CeFeO}$ to enable the continuity of free-radical quenching.

\section{Conclusion}

Ce-Fe complex oxides were successfully synthesized. A Ce-Fe complex oxide with $\mathrm{Ce} /(\mathrm{Ce}+\mathrm{Fe})$ molar ratio of 0.8 (CeFeO-0.8) could significantly improve the thermal oxidative stability of silicone rubber. After aging at $300^{\circ} \mathrm{C}$ for $24 \mathrm{~h}$, silicone rubber filled with 4 phr CeFeO-0.8 has higher retentions of tensile strength and elongation at break, smaller changing amplitude of crosslink density and lower conversion rate of the side methyl group compared with silicone rubbers filled pure $\mathrm{CeO}_{2}$ and $\mathrm{Fe}_{2} \mathrm{O}_{3} \cdot \mathrm{Ce}^{4+}$ and Fe ${ }^{3+}$ could react with radicals produced in the thermal degradation process of silicone rubber and the Ce and Fe in Ce-Fe complex oxide have positive synergistic effect on radical capturing as confirmed by XPS spectra. These results indicate that Ce-Fe complex oxides has good potential applications in the manufacture of heat resistant silicone rubber.

Acknowledgements: This work is supported by National Natural Science Foundation of China (No. 51273109).

\section{References}

1. Patel M., Skinner A.R., Thermal ageing studies on room-temperature vulcanized polysiloxane rubbers. Polym Degrad Stab, 2001, 73(3), 399-402.

2. Camino G., Lomakin S.M., Lazzari M., Polydimethylsiloxane thermal degradation, Part 1. Kinetic aspects. Polymer, 2001, 42(6), 2395-2402.

3. Camino G., Lomakin S.M., Legeard M., Thermal polydimethylsiloxane degradation Part 2. The degradation mechanisms. Polymer, 2002, 43(7), 2011-2015.

4. Thomas T.H., Kendrick T.C., Thermal analysis of polysiloxanes. II. Thermal vacuum degradation of polysiloxanes with different substituents on silicon and in the main siloxane chain. J Polym Sci, Part A: Polym Chem, 1970, 8, 1823-1830.

5. Warrick E.L., Pierce O.R., Polmanteer K.E., Saam J.C., Silicone Elastomer Developments 1967-1977. Rubber Chem Technol, 1979, 52(3), 437-525.

6. Hayashida O., Kazuhiro O., Atsuhito K., Silicone Rubber Composition Having Excellent Heat Resistance. 2015, EP2554585 B1.

7. Katusic S., Michael G.D., Miess H., Scholz M., Kunzmann K., Albers P., Pyrogenically-produced cerium oxide useful in polishing sensitive electronics surfaces, as a heat stabilizer for silicone rubber or as a catalyst has specified coarse and fine fractions. 2004, DE10251029 A1. 
8. Fei H.F., Han X.J., Liu B.Z., Gao X.Y., Wang Q., Zhang Z.J., et al., Mechanism of the antioxidation effect of $\alpha-\mathrm{Fe}_{2} \mathrm{O}_{3}$ on silicone rubbers at high temperature. RSC Adv, 2016, 6(10), 7717-7722.

9. Li H.Y., Tao S., Huang Y.H., Su Z.T., Zheng J.P., The improved thermal oxidative stability of silicone rubber by using iron oxide and carbon nanotubes as thermal resistant additives. Compos Sci Technol, 2013, 76, 52-60.

10. Zhang X., Zhang Q., Zheng J.P., Effect and mechanism of iron oxide modified carbon nanotubes on thermal oxidative stability of silicone rubber. Compos Sci Technol, 2014, 99, 1-7.

11. Bai L., Bai Y.L., Zheng J.P., Improving the filler dispersion and performance of silicone rubber/multi-walled carbon nanotube composites by noncovalent functionalization of polymethylphenylsiloxane. J Mater Sci, 2017, 52(12), 7516-7529.

12. Bai L., Wang X., Tan J., Li H.Y., Zheng J.P., Study of distinctions in the synergistic effects between carbon nanotubes and different metal oxide nanoparticles on enhancing thermal oxidative stability of silicone rubber. J Mater Sci, 2016, 51(15), 7130-7144.

13. Wu Y.L., Bai Y.L., Zheng J.P., Effects of Polyhedral Oligomeric Silsesquioxane Functionalized Multi-walled Carbon Nanotubes on Thermal Oxidative Stability of Silicone Rubber. Sci Adv Mater, 2014, 6(6), 1244-1254.

14. Qiu X.N., Cai H., Fang X., Zheng J.P., The improved thermal oxidative stability of silicone rubber by incorporating reduced graphene oxide: Impact factors and action mechanism. Polym Compos, 2018, 39(4), 1105-1115.

15. Chen D.Z., Yi S.P., Wu W.B., Zhong Y.L., Liao J., Huang C., et al., Synthesis and characterization of novel room temperature vulcanized (RTV) silicone rubbers using Vinyl-POSS derivatives as crosslinking agents. Polymer, 2010, 51(17), 3867-3878.

16. Liu Y.F., Shi Y.H., Zhang D., Li J.L., Huang G.S., Preparation and thermal degradation behavior of room temperature vulcanized silicone rubber-g-polyhedral oligomeric silsesquioxanes. Polymer, 2013, 54(22), 6140-6149.

17. Bai L., Zheng J., Synergistic effect of iron oxide modified carbon nanotubes on the thermal stability of silicone rubber under different atmospheres. J Therm Anal Calorim, 2016, 123(2), 1281-1291.

18. Liang C., Ma Z., Lin H., Ding L., Qiu J., Frandsen W., Su D., Template preparation of nanoscale $\mathrm{Ce}_{x} \mathrm{Fe}_{1-x} \mathrm{O}_{2}$ solid solutions and their catalytic properties for ethanol steam reforming. J Mater Chem, 2009, 19(10), 1417-1424.

19. Li K., Wang H., Wei Y., Yan D., Direct conversion of methane to synthesis gas using lattice oxygen of $\mathrm{CeO}_{2}-\mathrm{Fe}_{2} \mathrm{O}_{3}$ complex oxides. Chem Eng J, 2010, 156(3), 512-518.

20. Bao H., Chen X., Fang J., Jiang Z., Huang W., Structure-activity relation of $\mathrm{Fe}_{2} \mathrm{O}_{3}-\mathrm{CeO}_{2}$ composite catalysts in $\mathrm{CO}$ oxidation. Catal Lett, 2008, 125(1-2), 160-167.

21. Rocha M.A.L., Ángel G.D., Torres-Torres G., Cervante A., Vázquez A., Arrieta A., et al., Effect of the Pt oxidation state and $\mathrm{Ce}^{3+} / \mathrm{Ce}^{4+}$, ratio on the $\mathrm{Pt} / \mathrm{TiO}_{2}-\mathrm{CeO}_{2}$, catalysts in the phenol degradation by catalytic wet air oxidation (CWAO). Catal Today, 2015, 250, 145-154.

22. Kuang W., Fan Y., Yao K., Chen Y., Preparation and Characterization of Ultrafine Rare Earth Molybdenum Complex Oxide Particles. J Solid State Chem, 1998,140(2), 354-360.

23. Cornell R.M., Schwertmann U., The iron oxides: structure, properties, reactions, occurrence and uses. Mineral Mag, 1997, 61(5), 740-741.

24. Elias J.S., Risch M., Giordano L., Mansour A.N., Shao-Hom Y., Structure, Bonding, and Catalytic Activity of Monodisperse, Transition-Metal-Substituted $\mathrm{CeO}_{2}$ Nanoparticles. J Am Chemi Soc, 2014, 136(49), 17193-17200.

25. Zhang Z., Han D., Wei S., Zhang Y., Determination of active site densities and mechanisms for soot combustion with $\mathrm{O}_{2}$, on Fe-doped $\mathrm{CeO}_{2}$, mixed oxides. J Catal, 2010, 276(1), 16-23.

26. Mcbride J.R., Hass K.C., Poindexter B.D., Weber W.H., Raman and $x$-ray studies of $\mathrm{Ce}_{1-x} \mathrm{RE}_{x} \mathrm{O}_{2-y}$, where $\mathrm{RE}=\mathrm{La}, \mathrm{Pr}, \mathrm{Nd}, \mathrm{Eu}, \mathrm{Gd}$, and Tb. J Appl Phys, 1998, 76(4), 2435-2441.

27. Gu J.W., Meng X.D., Tang Y.S., Yang L., Zhuang Q., Kong J., Hexagonal boron nitride/silicone rubber dielectric thermally conductive composites with excellent thermal stabilities. Compos Part A-Appl S, 2017, 92, 27-32.

28. Gu J.W., Lv Z.Y., Wu Y.L., Guo Y.Q., Tian L.D., Qiu H., et al., Dielectric thermally conductive boron nitride/polyimide composites with outstanding thermal stabilities via in-situ polymerizationelectrospinning-hot press method. Compos Part A-Appl S, 2017, 94, 209-216.

29. Gu J., Dong W., Xu S., Tang Y., Ye L., Kong J., Development of wave-transparent, light-weight composites combined with superior dielectric performance and desirable thermal stabilities. Compos Sci Technol, 2017, 144, 185-192.

30. Qiu J., Lai X., Li H., Zeng X., Zhang Z., Synthesis of ZirconiumContaining Polyhedral Oligometallasilsesquioxane as an Efficient Thermal Stabilizer for Silicone Rubber. Polymers, 2018, 10(5), 520.

31. Katta L., Kumar T.V., Durgasri D.N., Reddy B.M., Nanosized $\mathrm{Ce}_{1-x} \mathrm{La}_{x} \mathrm{O}_{2-\delta} / \mathrm{Al}_{2} \mathrm{O}_{3}$ solid solutions for $\mathrm{CO}$ oxidation: Combined study of structural characteristics and catalytic evaluation. Catal Today, 2012, 198(1), 133-139.

32. Lin T.N., Lee M.C., Yang R.J., Chang J.C., Kao W.X., Lee L.S., Chemical state identification of $\mathrm{Ce}^{3+} / \mathrm{Ce}^{4+}$, in the $\mathrm{Sm}_{0.2} \mathrm{Ce}_{0.8} \mathrm{O}_{2-\delta}$, electrolyte for an anode-supported solid oxide fuel cell after long-term operation. Mater Lett. 2012, 81, 185-188.

33. Aronniemi M., Sainio J., Lahtinen J., Chemical state quantification of iron and chromium oxides using XPS: the effect of the background subtraction method. Surf Sci, 2005, 578(1-3), 108-123.

34. Roosendaal S.J., Asselen B.V., Elsenaar J.W., Vredenberg A.M., Habraken F.H.P.M., The oxidation state of $\mathrm{Fe}(100)$ after initial oxidation in $\mathrm{O}_{2}$. Surf $\mathrm{Sci}, 1999,442(3), 329-337$. 